\title{
PENGARUH PERLAKUAN LARUTTAN PERENDAM TERHADAP KADAR UREA DAGING CUCUT SEGAR DAN MUTU DAGING ASAPNYA
}

\author{
Mohammad Saleh $^{*}$, Irwandi**) F.G. Winarno
dan Y. Haryadi
(**)
}

\begin{abstract}
ABSTRAK
Dalam penelitian ini telah dilakukan tiga macam perlakuan larutan perendam daging ikan cucut, yaitu: dalam (i) larutan enzim urease $0,025 \%$ (A1), (ii) larutan asam asetat $2 \%$ dan dilanjutkan dalam larutan garam $10 \%$ (A2), dan (iii) larutan enzim urease $0,025 \%$ dilanjutkan dalam larutan asam asetat $2 \%$ dan akhirnya dalam larutan garam $10 \%$ A3). Lama perendaman pada tiap-tiap larutan tersebut adalah 20 menit. Daging cucut kemudian diasap selama 7 jam lalu dikemas dalam kantong plastik dan disimpan pada suhu karnar dan suhu rendah $\left(4^{\circ} \mathrm{C}\right)$. Pengamatan dilakukan untuk mengetahui pengaruh ketiga perlakuan tersebut terhadap kadar urea daging cucut segar serta perubahan mutu daging cucut asapnya selama penyimpanan.
\end{abstract}

Hasil pengamatan menunjukkan bahwa perlakuan A1 dan A3 sangat efektif dalam mengurangi kadar urea daging cucut segar. Perlakuan A1 dan A3 masing-masing dapat mengurangi kadar urea sebesar $\mathbf{9 0 , 3 5 \% ~ d a n ~} \mathbf{9 8 , 1 9 \%}$. Sedangkan perlakuan A2 kurang efektif karena hanya mampu mengurangi urea sebesar $29,31 \%$. Daging cucut asap yang disimpan pada suhu kamar hanya tahan selama 4 hari sedangkan pada suhu rendah lebih dari 16 hari. Perlakuan perendaman sebelum pengasapan dapat memperpanjang daya awet cucut asap pada suhu kamar menjadi lebih dari 6 hari dan pada suhu rendah lebih dari 24 hari. Selama penyimpanan pada kedua kondisi tersebut terjadi penurunan kadar air, urea, fenol dan nilai organoleptiknya sedangkan kadar TVB, amoniak dan TPC mengalami peningkatan. Pada suhu kamar daging cucut asap ditumbuhi oleh kapang Aspergillus sp., A.niger, Penicillium sp. dan Alternaria sp. sedangkan pada suhu rendah hanya Aspergillus sp. dan A.niger.

\section{ABSTRACT: Effect of Dipping Solution Treatment on Urea Content of Fresh Shark Meat and Quality Changes of Its Smoked Product, by: Mobammad Saleb, Irwandi, F.G. Winarno and Y. Haryadi.}

In this study three dipping treatments prior to smoking of shark meat had been excercised. The treatments were (i) dipping in $0.025 \%$ urease solution (A1),(ii) dipping in $2 \%$ acetic acid solution followed by dipping in $10 \%$ salt solution (A2), and (iii) dipping in $0.025 \%$ urease solution, followed by dipping in $2 \%$ acetic acid solution and lastly in 10\% salt solution (A3). Dipping periods for each solution were the same i.e. 20 minutes. Smoking was done by hot smoking for 7 hours. Smoked shark meat was packed in polyethylene bags and stored at room and low temperature $\left(4^{\circ} \mathrm{C}\right)$. Observations were carried out to study the effect of dipping treatment on urea content of fresh shark meat and quality changes of smoked shark meat during storage.

It was found that dipping treatment $\mathrm{A} 1$ and $\mathrm{A} 3$ were very effective in reducing urea content as it reduced urea content of shark meat up to $90.35 \%$ and $98.19 \%$ respectively.

*) Peneliti pada Instalasi Penelitian Perikanan Laut Slipi, Jakarta

"*) Mahasiswa Fakultas Pertanian, IPB

${ }^{* * *}$ ) Pengajar pada Fakultas Teknologi Pertanian, IPB 
Treatment A2 was less effective, with urea content reduced by only $29.31 \%$. The shelf-life of smoked shark meat at room temperature was only 4 days and at low temperature was 16 days. Dipping treatment prior to smoking increased shelf-life of smoked shark meat at room temperature to 6 days and at low temperature more than 24 days. The content of moisture, urea and phenol of smoked shark meat tended to decrease during storage, but TVB, ammonia and TPC were increased. It was observed that at room temperature smoked shark meat was attacked by Aspergillus sp., A.niger, Penicillium sp. dan Alternaria sp., while at low temperature only by Aspergillus sp. and A.niger.

KEYWORDS: Sbarks, wrea contents, smoked sbark meat

\section{PENDAHULUAN}

Kecuali di daerah Jawa Barat, daging ikan cucut mempunyai nilai ekonomi yang masih rendah bahkan di beberapa daerah tidak dimanfaatkan sama sekali (Sabaruddin et al., 1987; Saleh et al., 1990). Hal ini terutama disebabkan karena daging cucut berbau spesifik yang dihasilkan dari penguraian urea yang terdapat dalam tubuh ikan cucut menjadi amoniak (Simidu, 1961).

Beberapa usaha telah dilakukan untuk mengurangi bau amoniak daging cucut antara lain dengan jalan perendaman dalam larutan asam, alkali dan garam serta perlakuan fisik (Berhimpon, 1982; Priono et al., 1984). Selain itu dalam rangka mengoptimalkan pemanfaatan daging cucut telah dilakukan beberapa penelitian pengolahan daging cucut menjadi berbagai bentuk olahan produk seperti sosis, bakso, abon dan tepung ikan mutu pangan (Sabaruddin et al., 1987; Saleh et al., 1990).

Bentuk olahan lain yang mungkin dapat dikembangkan adalah daging cucut asap. Dalam penelitian ini telah dilakukan beberapa perlakuan perendaman daging cucut sebelum diasap dengan tujuan untuk mengetahui pengaruh perlakuan tersebut terhadap perubahan mutu kimia, mikrobiologi dan organoleptik daging cucut asap yang disimpan pada suhu kamar dan suhu rendah. Diharapkan hasil penelitian ini dapat memberikan alternatif pemanfaatan daging ikan cucut.

\section{BAHAN DAN METODE}

\section{Bahan}

(1) Bahan baku ikan cucut yang digunakan untuk penelitian dibeli di T.P.I. Pelabuhan Ratu, Jawa Barat dengan berat sekitar $55 \mathrm{~kg}$. Setelah dibuang kepala dan isi perutnya, ikan dipotong menjadi beberapa bagian kemudian dimasukkan ke dalam peti berinsulasi yang diberi es hancuran secukupnya dan segera diangkut ke Jakarta. Keesokan harinya dilakukan pembuangan kulit dan dagingnya dipotong-potong menjadi bentuk steak dengan ukuran $13 \times 8 \times 0,8 \mathrm{~cm}$, kemudian dicuci bersih hingga bebas dari sisa-sisa darah dan kotoran lainnya. 
(2) Enzim urease diperoleh dari SIGMA Chemical Company Amerika Serikat dengan spesifikasi nomor produk U 8876 yang mempunyai aktivitas sebesar 6.000-12.000 unit per gram solid. Ekstrak enzim urease dilarutkan pada larutan buffer fosfat pada $\mathrm{pH} 7$ dan suhu sekitar $25^{\circ} \mathrm{C}$.

\section{Metode Penelitian}

Steak daging cucut yang akan diasap diberi perlakuan perendaman menurut perlakuan yang ditentukan, perbandingan antara volume larutan perendam dan bobot steak adalah 2 : 1 sehingga daging terendam dalam larutan. Perlakuan perendaman yang dicoba adalah sbb.:

$\mathrm{A}_{\mathrm{o}} \quad=$ Tanpa perlakuan perendaman (kontrol).

$A_{1}=$ Perendaman dalam larutan enzim urease $0,025 \%$.

$\mathrm{A}_{2}=$ Perendaman dalam larutan asam asetat $2 \%$ dilanjutkan dengan perendaman dalam larutan garam $10 \%$.

$\mathrm{A}_{3}=$ Perendaman dalam larutan enzim urease, dilanjutkan dengan perendaman dalam larutan asam asetat $2 \%$ dan akhirnya dalam larutan garam $10 \%$.

Lama perendaman dalam tiap-tiap larutan adalah sama yaitu 20 menit. Setelah perendaman steak dibilas dengan air kemudian ditiriskan untuk beberapa saat, lalu diikat dengan benang, selanjutnya digantung dalam kamar asap. Pengasapan dilakukan dengan pengasapan dingin (suhu kamar asap sekitar $40^{\circ} \mathrm{C}$ ) selama sekitar satu jam dilanjutkan dengan pengasapan panas (suhu kamar asap sekitar $70^{\circ} \mathrm{C}$ ) selama 6 jam. Daging yang telah diasap dibiarkan beberapa saat sehingga suhunya mencapai suhu ruang, kemudian dikemas dalam kantong polietilen (PE) yang mempunyai ketebalan 0,05 mm. Contoh dibagi menjadi dua kelompok, kelompok I disimpan pada suhu ruang (sekitar $27^{\circ}-28^{\circ} \mathrm{C}$ ) dan kelompok II disimpan pada ruang pendingin (chill room) yang mempunyai suhu sekitar $4^{\circ} \mathrm{C}$.

\section{Rancangan Percobaan}

Percobaan dilakukan dengan menggunakan rancangan acak lengkap (RAL) dengan satu faktor yaitu jenis perendaman dengan dua kali ulangan.

\section{Jenis Pengamatan}

Penelitian diawali dengan pengamatan kondisi kimiawi dan mikrobiologi bahan baku ikan yang digunakan, untuk mengetahui dengan pasti kondisi awalnya. Pengamatan berikutnya dilakukan terhadap kadar urea dari contoh kontrol dan contoh yang diperlakukan untuk melihat efektifitas perlakuan terhadap penurunan kadar urea. 
Selanjutnya pengamatan kimiawi, mikrobiologi dan organoleptik dilakukan terhadap daging cucut asap kontrol dan yang diperlakukan, baik yang disimpan pada suhu kamar maupun pada suhu rendah. Pengamatan untuk contoh yang disimpan pada suhu kamar dilakukan tiap hari dimulai hari ke 0 sampai hari ke 6 dan untuk yang disimpan pada suhu rendah pengamatan dilakukan setiap 8 hari dimulai hari ke 0 sampai ke 24 .

\section{Metode Analisis}

- Pengamatan kimiawi:

Pengamatan kimia mencakup analisis proksimat dan TVB (Anonim, 1974), urea dan amoniak dengan metode spektrofotometer (AOAC, 1980) dan fenol dengan metode titrasi (AOAC, 1970).

\section{- Pengamatan mikrobiologis:}

Pengamatan mikrobiologis dilakukan terhadap TPC yang dilakukan dengan metode tuang pada media nutrien agar (Anonim, 1974) dan identifikasi kapang dengan metode tuang pada media potato dextrose agar dilanjutkan dengan menginokulasikan pada media dicloran rose bengal clorampenicol agar, czapek yeast agar dan malt extract agar (Pitt dan Hocking, 1985).

\section{- Pengamatan organoleptik:}

Pengamatan organoleptik dilakukan dengan metode uji hedonik skala 1 sampai 9 dengan nilai tertinggi 9, terendah 1 dan batas penerimaan 5. Pengamatan dilakukan terhadap penampakan, bau, rasa, dan tekstur. Produk dinyatakan ditolak jika skor salah satu parameter mutu organoleptik telah mencapai 5 atau kurang.

\section{HASIL DAN PEMBAHASAN}

\section{Analisis Daging Ikan Cucut Segar}

Hasil analisis kimia dan mikrobiologi daging ikan cucut segar terhimpun dalam Table 1. Hasil analisis urea pada daging cucut yang berasal dari bagian ekor, perut dan punggung menunjukkan bahwa kadarnya tidak berbeda yaitu $1,81 \%$ (bobot basah) atau 7,64\% ( bobot kering). Dengan demikian untuk percobaan daging yang digunakan dapat berasal dari ketiga bagian tersebut. 
Table 1. Chemical and microbiological analysis of fresh shark meat (mean of two replication)

\begin{tabular}{|c|c|c|c|}
\hline \multicolumn{2}{|c|}{ Parameter } & Wet base & Dry base \\
\hline Moisture & $(\%)$ & 76.33 & - \\
\hline$A s h$ & (\%) & 1.22 & 5.14 \\
\hline Crude protein & (\%) & 21.34 & 90.23 \\
\hline Fat & $(\%)$ & 0.37 & 1.55 \\
\hline Urea & (\%) & 1.81 & 7.64 \\
\hline Amonia & $(m g N \%)$ & 15.43 & - \\
\hline$T V B$ & $(m g N \%)$ & 24.40 & - \\
\hline$p H$ & & 5.96 & - \\
\hline$T P C$ & (colony/g) & $1.9 \times 10^{4}$ & \\
\hline
\end{tabular}

\section{Pengaruh Perlakuan Perendaman terhadap Kadar Urea Daging Cucut Segar}

Hasil analisis kemampuan setiap jenis perendaman dalam mereduksi kandungan urea daging cucut dapat dilihat pada Table 2 . Ternyata perendaman steak dalam larutan enzim urease sangat efektif dalam mereduksi kandungan urea dalam daging cucut. Perlakuan tersebut dapat menurunkan kandungan urea sebesar $90,35 \%$, (\% bobot kering) sedangkan perlakuan dengan ureaseasetat- $\mathrm{NaCl}$ bahkan dapat menurunkan kadar urea sebesar $\mathbf{9 8 , 1 9 \%}$. Sebaliknya perlakuan dengan asetat- $\mathrm{NaCl}$ hanya sanggup mereduksi urea sebesar $29,31 \%$.

Table 2. Urea content of shark meat after some dipping treatments (mean of two replicaion)

\begin{tabular}{lc}
\hline \multicolumn{1}{c}{ Treatment } & Urea (\%db) \\
\hline - Control (Ao). & 7.64 \\
- Dipping in 0.025\% urease solution (A1). & 0.80 \\
- Dipping in acetic acid 2\%, followed by dipping in & 5.86 \\
10\% brine solution (A2). & \\
- Dipping in 0.025\% urease soln. followed by dipping & 0.15 \\
in acetic acid and lastly dipping in 10\% brine \\
(A3).
\end{tabular}

Enzim urease akan menguraikan senyawa urea menjadi $\mathrm{NH}_{3}$ dan $\mathrm{CO}_{2}$ pada pH sekitar netral seperti reaksi berikut:

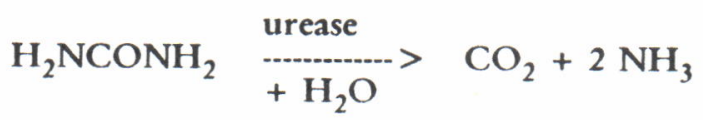


Pada perlakuan A2 berkurangnya kadar urea daging cucut diduga karena larut dalam larutan asam. Selain itu urea dapat larut dengan baik dalam air, etanol, metanol, dan pirimidin (Weast, 1976).

Hasil Pengamatan Kimiawi, Mikrobiologis dan Organoleptik Daging Cucut Asap

Hasil analisis kimiawi dan mikrobiologis daging cucut asap terhimpun dalam Table 3 dan Table 4.

Table 3. Chemical and microbiological analysis of smoked shark meat during storage at room temperature

\begin{tabular}{|c|c|c|c|c|c|c|c|}
\hline Treatment & $\begin{array}{l}\text { Storage } \\
\text { (days) }\end{array}$ & $\begin{array}{c}\text { Moisture } \\
\text { (\%) }\end{array}$ & $\begin{array}{l}\text { Urea } \\
\text { (\%db) }\end{array}$ & $\begin{array}{l}\text { Ammonia } \\
(m g N \% d b)\end{array}$ & $\begin{array}{c}\text { TVB } \\
m g N \% d b)\end{array}$ & $\begin{array}{c}\text { Pbenol } \\
\text { (mgN\%db) }\end{array}$ & $\log T P C$ \\
\hline \multirow[t]{7}{*}{ Ao } & 0 & 44.73 & 6.67 & 42.8 & 73.5 & 3.5 & 2.92 \\
\hline & 1 & 43.01 & 6.06 & 46.4 & 77.6 & 3.4 & 3.91 \\
\hline & 2 & 42.82 & 6.00 & 49.4 & 96.9 & 3.3 & 4.07 \\
\hline & 3 & 41.50 & 5.78 & 54.8 & 119.1 & 2.8 & 4.95 \\
\hline & 4 & 41.20 & 5.74 & 59.9 & 140.5 & 1.4 & 5.96 \\
\hline & 5 & 39.30 & 5.57 & 61.2 & 159.7 & 1.8 & 6.37 \\
\hline & 6 & 40.24 & 5.28 & 67.6 & 207.8 & 1.0 & 6.81 \\
\hline \multirow[t]{7}{*}{$A 1$} & 0 & 45.48 & 0.05 & 59.2 & 129.8 & 4.1 & 2.86 \\
\hline & 1 & 43.33 & 0.01 & 60.9 & 157.9 & 3.9 & 3.02 \\
\hline & 2 & 41.09 & 0.00 & 61.8 & 178.9 & 3.7 & 4.00 \\
\hline & 3 & 40.40 & 0.00 & 64.9 & 190.6 & 3.2 & 4.75 \\
\hline & 4 & 40.34 & 0.00 & 66.9 & 196.2 & 2.5 & 5.72 \\
\hline & 5 & 39.94 & 0.00 & 67.9 & 206.5 & 2.0 & 5.90 \\
\hline & 6 & 40.24 & 0.00 & 69.8 & 218.1 & 1.4 & 6.00 \\
\hline \multirow[t]{7}{*}{$A 2$} & 0 & 42.93 & 5.52 & 30.0 & 76.6 & 4.1 & 2.81 \\
\hline & 1 & 42.24 & 5.32 & 33.7 & 82.9 & 4.0 & 2.99 \\
\hline & 2 & 41.41 & 5.06 & 36.3 & 87.0 & 3.8 & 4.02 \\
\hline & 3 & 40.95 & 4.99 & 39.6 & 104.4 & 3.9 & 4.73 \\
\hline & 4 & 40.39 & 4.66 & 40.8 & 115.1 & 2.6 & 5.71 \\
\hline & 5 & 39.06 & 4.13 & 43.6 & 124.2 & 2.0 & 5.85 \\
\hline & 6 & 39.57 & 3.99 & 44.3 & 140.0 & 1.5 & 6.02 \\
\hline \multirow[t]{7}{*}{$A 3$} & 0 & 45.97 & 0.03 & 65.5 & 154.0 & 4.0 & 2.57 \\
\hline & 1 & 45.32 & 0.01 & 65.6 & 174.2 & 4.0 & 2.92 \\
\hline & 2 & 42.91 & 0.00 & 68.1 & 184.0 & 3.7 & 3.96 \\
\hline & 3 & 42.79 & 0.00 & 70.1 & 194.4 & 3.2 & 4.70 \\
\hline & 4 & 39.57 & 0.00 & 71.7 & 200.3 & 2.5 & 5.00 \\
\hline & 5 & 40.03 & 0.00 & 72.3 & 211.7 & 1.9 & 5.38 \\
\hline & 6 & 40.61 & 0.00 & 73.3 & 225.6 & 1.4 & 5.71 \\
\hline
\end{tabular}

Ao $=$ Control

A1 = Dipping in $0.025 \%$ urease soln.

A2 = Dipping in acetic acid 2\%,followed by dipping in 10\% brine soln.

A3 = Dipping in urease solution followed by dipping in acetic acid, lastly in $10 \%$ brine. 
Table 4. Chemical and microbiological analysis of smoked shark during storage at low temperature

\begin{tabular}{|c|c|c|c|c|c|c|c|}
\hline Treatment & $\begin{array}{l}\text { Storage } \\
\text { (days) }\end{array}$ & $\begin{array}{c}\text { Moisture } \\
\text { (\%) }\end{array}$ & $\begin{array}{l}\text { Urea } \\
\text { (\%db) }\end{array}$ & $\begin{array}{l}\text { Ammonia } \\
(m g N \% d b)\end{array}$ & $\begin{array}{c}T V B \\
\operatorname{mgN} \% d b)\end{array}$ & $\begin{array}{c}\text { Pbenol } \\
\text { (mgN\%db) }\end{array}$ & $\log T P C$ \\
\hline \multirow[t]{4}{*}{ Ao } & 0 & 44.73 & 6.67 & 42.8 & 73.5 & 3.5 & 2.92 \\
\hline & 8 & 42.40 & 5.42 & 44.6 & 87.2 & 1.8 & 3.68 \\
\hline & 16 & 39.33 & 5.19 & 47.0 & 92.3 & 1.6 & 5.88 \\
\hline & 24 & 40.94 & 4.96 & 51.2 & 106.5 & 1.4 & 6.22 \\
\hline \multirow[t]{4}{*}{$A 1$} & 0 & 45.48 & 0.05 & 59.2 & 129.8 & 4.1 & 2.86 \\
\hline & 8 & 42.99 & 0.01 & 61.4 & 141.7 & 2.2 & 3.00 \\
\hline & 16 & 40.20 & 0.00 & 63.9 & 155.8 & 2.0 & 4.04 \\
\hline & 24 & 41.42 & 0.00 & 65.0 & 168.8 & 1.9 & 5.75 \\
\hline \multirow[t]{4}{*}{$A 2$} & 0 & 42.93 & 5.51 & 30.0 & 76.6 & 4.1 & 2.81 \\
\hline & 8 & 40.59 & 4.94 & 31.3 & 78.4 & 2.4 & 3.00 \\
\hline & 16 & 40.09 & 4.59 & 35.2 & 89.9 & 2.2 & 4.04 \\
\hline & 24 & 40.26 & 3.16 & 38.7 & 101.7 & 2.0 & 5.75 \\
\hline \multirow{4}{*}{$A 3$} & 0 & 45.97 & 0.03 & 65.5 & 154.0 & 4.0 & 2.57 \\
\hline & 8 & 46.23 & 0.01 & 67.8 & 161.5 & 2.1 & 2.82 \\
\hline & 16 & 42.43 & 0.00 & 69.4 & 168.5 & 1.9 & 3.74 \\
\hline & 24 & 41.56 & 0.00 & 70.7 & 206.7 & 1.8 & 5.00 \\
\hline
\end{tabular}

\section{(1) Kadar air}

Kadar air daging cucut asap pada semua perlakuan selama waktu penyimpanan antara 39 sampai $45 \%$. Hasil analisis ragam tidak memperlihatkan perbedaan nyata pengaruh perlakuan terhadap kadar air. Kadar air pada semua contoh sejak hari ke 0 sampai hari ke 5 mengalami penurunan, namun pada hari terakhir terjadi sedikit peningkatan. Terjadinya penurunan kadar air diduga berkaitan dengan proses penguapan dari produk karena pengaruh suhu udara dan kelembaban lingkungan sedangkan adanya peningkatan kadar air mungkin disebabkan oleh aktivitas mikroorganisme yang menguraikan struktur molekul protein sehingga membebaskan air terikat menjadi air bebas (Winarno et al.,1980).

\section{(2) Kadar urea}

Analisis ragam terhadap kadar urea menunjukkan bahwa jenis perlakuan perendaman berpengaruh sangat nyata terhadap kadar urea daging cucut asap. Perendaman telah mengurangi sebagian besar kadar urea daging cucut. Setelah 
perendaman, urea yang masih ada pada contoh daging cucut segar dengan perlakuan larutan urease $\left(A_{1}\right)$ sebesar $0,80 \%$ (bobot kering), dengan perlakuan larutan-larutan asetat dan $\mathrm{NaCl}\left(\mathrm{A}_{2}\right)$ sebesar $0,15 \%$ dan yang dengan perlakuan larutan-larutan urease, asetat dan $\mathrm{NaCl}\left(\mathrm{A}_{3}\right)$ sebesar $5,86 \%$, sedangkan pada kontrol $\left(\mathrm{A}_{0}\right)$ adalah $7,64 \%$.

Selama penyimpanan daging cucut asap baik pada suhu kamar maupun suhu rendah, semua perlakuan memperlihatkan kecenderungan penurunan kadar urea. Kadar urea pada cucut asap dengan perlakuan larutan urease dan perlakan larutan urease, asetat dan $\mathrm{NaCl}$ bahkan sudah tak terdeteksi lagi pada hari kedua penyimpanan pada suhu kamar dan pada hari ke-16 penyimpanan pada suhu rendah. Pada hari-hari pengamatan tersebut, kadar urea yang tersisa pada contoh dengan perlakuan larutan urease dan larutan-larutan urease, asetat dan $\mathrm{NaCl}$ adalah sama. Dengan demikian perendaman dalam larutan asetat dan $\mathrm{NaCl}$ setelah perendaman dalam urease menjadi kurang efektif dan tidak ekonomis.

Terjadinya penurunan kadar urea selama penyimpanan mungkin disebabkan oleh aktivitas mikroorganisme yang memproduksi enzim urease. Makin lama waktu penyimpanan, jumlah mikroorganisme makin tinggi sehingga enzim urease yang dihasilkan makin banyak. Mikroorganisme ini mungkin berasal dari pencemaran yang terjadi selama penanganan daging cucut segar dan tidak seluruhnya mati pada saat pengasapan.

\section{(3) Kadar amoniak}

Dari hasil analisis sidik ragam terlihat bahwa jenis perlakuan perendaman berpengaruh sangat nyata terhadap kadar amoniak daging cucut asap baik pada penyimpanan suhu kamar maupun suhu rendah. Selama penyimpanan, baik pada suhu kamar maupun pada suhu rendah terjadi peningkatan kadar amoniak. Selain karena terjadi penguraian urea oleh enzim urease yang dihasilkan mikroorganisme, kemungkinan lain karena terjadi pula perombakan asam-asam amino (Berhimpon, 1982).

Urea merupakan sumber potensial amoniak, hampir semua penelitian tentang ikan cucut diarahkan untuk menekan kadar urea serendah mungkin dengan cara menguraikannya menjadi amoniak yang selanjutnya akan menguap sehingga mengurangi bau pesing daging ikan cucut. Pada penelitian ini, kadar urea pada contoh yang mendapat perlakuan perendaman dalam larutan urease, dan larutan urease, asetat dan $\mathrm{NaCl}$ telah jauh berkurang bahkan pada daging cucut asapnya sudah tidak terdeteksi lagi pada hari ke-2. Namun demikian kadar amoniaknya cenderung meningkat, meskipun secara organoleptik tidak berpengaruh karena terdapatnya aroma asap. Pada mulanya diharapkan dengan menguraikan urea sebanyak mungkin, kadar amoniak yang tersisa juga rendah, karena amoniak bersifat mudah menguap dan mudah larut dalam air. Masih 
tingginya kadar amoniak pada kedua contoh tersebut diduga karena tidak semua amoniak yang terbentuk selama perendaman menguap ketika contoh diasap. Sebagian di antaranya mungkin terperangkap di dalam jaringan daging sehingga sulit menguap.

\section{(4) Kadar total volatile base (TVB)}

Dari hasil analisis ragam pada kedua kondisi penyimpanan terlihat bahwa perlakuan perendaman berpengaruh sangat nyata terhadap kadar TVB. Selama penyimpanan kadar TVB pada semua contoh cenderung meningkat, dan mencapai nilai tertinggi pada hari terakhir penyimpanan. Peningkatan ini sejalan dengan peningkatan kadar amoniak dan penurunan kadar urea.

Peningkatan kadar TVB pada semua perlakuan penyimpanan berkaitan dengan pemecahan protein menjadi senyawa-senyawa sederhana yang mengandung basa menguap seperti amoniak dan trimetil amin (TMA) (Soedijono et al., 1984). Seperti halnya amoniak, peningkatan kadar TVB pada suhu rendah lebih lambat dibandingkan pada suhu kamar. Hal ini karena pada suhu rendah mikroorganisme terhambat pertumbuhannya.

\section{(5) Kadar fenol}

Walaupun analisis ragam menunjukkan bahwa jenis perlakuan berpengaruh sangat nyata terhadap kadar fenol daging cucut asap, namun perbedaan antara kadar fenol cucut asap kontrol dan daging cucut asap yang mendapat perlakuan relatif kecil. Selama penyimpanan baik pada suhu kamar maupun pada suhu rendah, kadar fenol cenderung menurun. Pada awal penyimpanan suhu kamar, kadar fenol contoh kontrol dan contoh yang mendapat perlakuan masing-masing sekitar 3,5 $\mathrm{mg} \%$ dan $4,1 \mathrm{mg} \%$, dan pada akhir penyimpanan masing-masing turun menjadi $1,0 \mathrm{mg} \%$ dan $1,8 \mathrm{mg} \%$.

Kadar fenol pada permukaan bahan yang diasap berbeda dengan kadar fenol pada bagian dalam (Cutting, 1965). Bila fenol tidak terserap ke bagian dalam bahan, kadar fenol dapat berkurang karena fenol memiliki sifat sensitif terhadap cahaya dan oksigen. Hal ini yang menyebabkan terjadinya penurunan kadar fenol selama penyimpanan. Bersama formaldehid dan senyawa asap lainnya, fenol berpengaruh sangat baik terhadap produk yang diasap karena dapat menghambat pertumbuhan mikroorganisme.

\section{(6) Jumlah hitung bakteri (total plate count/TPC)}

Hasil analisis jumlah hitung bakteri (TPC) daging cucut segar adalah $1,9 \times 10^{4} \mathrm{koloni} /$ gram dan TPC daging cucut asap pada awal penyimpanan berkisar antara $3,8 \times 10^{2}-8,3 \times 10^{2}$. Berkurangnya TPC disebabkan karena banyaknya bakteri yang tidak tahan suhu tinggi dan senyawa-senyawa kimia 
(fenol, formaldehid, dll.) yang terbentuk selama pengasapan. Motohiro (1988) menyatakan bahwa pengasapan selama 3 jam dapat mematikan Bacillus subtilis, 18 jam dapat mematikan spora Bacillus antbracis dan 2 sampai 5 jam efektif mematikan Staphylococcus aureus dan S. pyogenes.

Dari analisis sidik ragam terlihat bahwa pada kedua kondisi penyimpanan, jenis perlakuan perendaman berpengaruh sangat nyata terhadap TPC daging cucut asap. Pada Table 3 dan Table 4 terlihat bahwa TPC daging cucut asap kontrol lebih tinggi daripada TPC daging cucut asap A1, A2 dan A3. Hal ini kemungkinan disebabkan karena pengaruh perendaman dalam garam dan asam asetat yang dapat mengurangi TPC serta kadar fenol pada contoh kontrol yang lebih rendah daripada contoh $\mathrm{A} 1, \mathrm{~A} 2$ dan $\mathrm{A} 3$.

Terlihat bahwa selama penyimpanan jumlah TPC meningkat, hal ini sejalan dengan berkurangnya jumlah fenol. Pada awal penyimpanan nilai logaritma TPC hanya meningkat sedikit atau cenderung mendatar, tetapi setelah itu terlihat peningkatan yang sangat cepat. Contoh yang disimpan pada suhu rendah mempunyai TPC yang relatif lebih rendah dibandingkan contoh yang disimpan pada suhu kamar.

\section{(7) Identifikasi kapang}

Pengamatan secara visual menunjukkan bahwa pada penyimpanan suhu kamar, contoh yang mengalami perlakuan perendaman mulai ditumbuhi kapang setelah hari ke 6, sedangkan kontrol sejak hari ke 4. Pada penyimpanan suhu rendah, contoh yang mengalami perlakuan perendaman belum ditumbuhi kapang hingga hari ke 24, tetapi kontrol sudah mulai ditumbuhi kapang sejak hari ke 19. Dengan demikian perendaman dapat menghambat pertumbuhan kapang.

Dari hasil identifikasi kapang terlihat bahwa jenis kapang yang tumbuh pada contoh yang disimpan pada suhu kamar lebih banyak dibandingkan contoh yang disimpan pada suhu rendah. Jenis- jenis kapang yang tumbuh pada contoh yang disimpan pada suhu kamar adalah Aspergillus sp., A.niger, Penicillium sp. dan Alternaria sp. Kapang jenis terakhir ini hanya ditemukan pada contoh kontrol. Sedangkan hasil identifikasi pada contoh kontrol dan contoh perlakuan yang disimpan pada suhu rendah hanya menemukan Aspergillus sp. dan A.niger. Adanya perbedaan baik pada jumlah maupun jenis kapang pada kedua kondisi penyimpanan tersebut selain perbedaan suhu mungkin karena perbedaan pada kadar fenol contoh.

\section{(8) Pengamatan organoleptik}

Hasil pengamatan organoleptik daging cucut asap selama penyimpanan pada suhu kamar dan suhu rendah terhimpun dalam Table 5 dan Table 6. 
Table 5. Organoleptic score of smoked shark meat during storage at room temperature

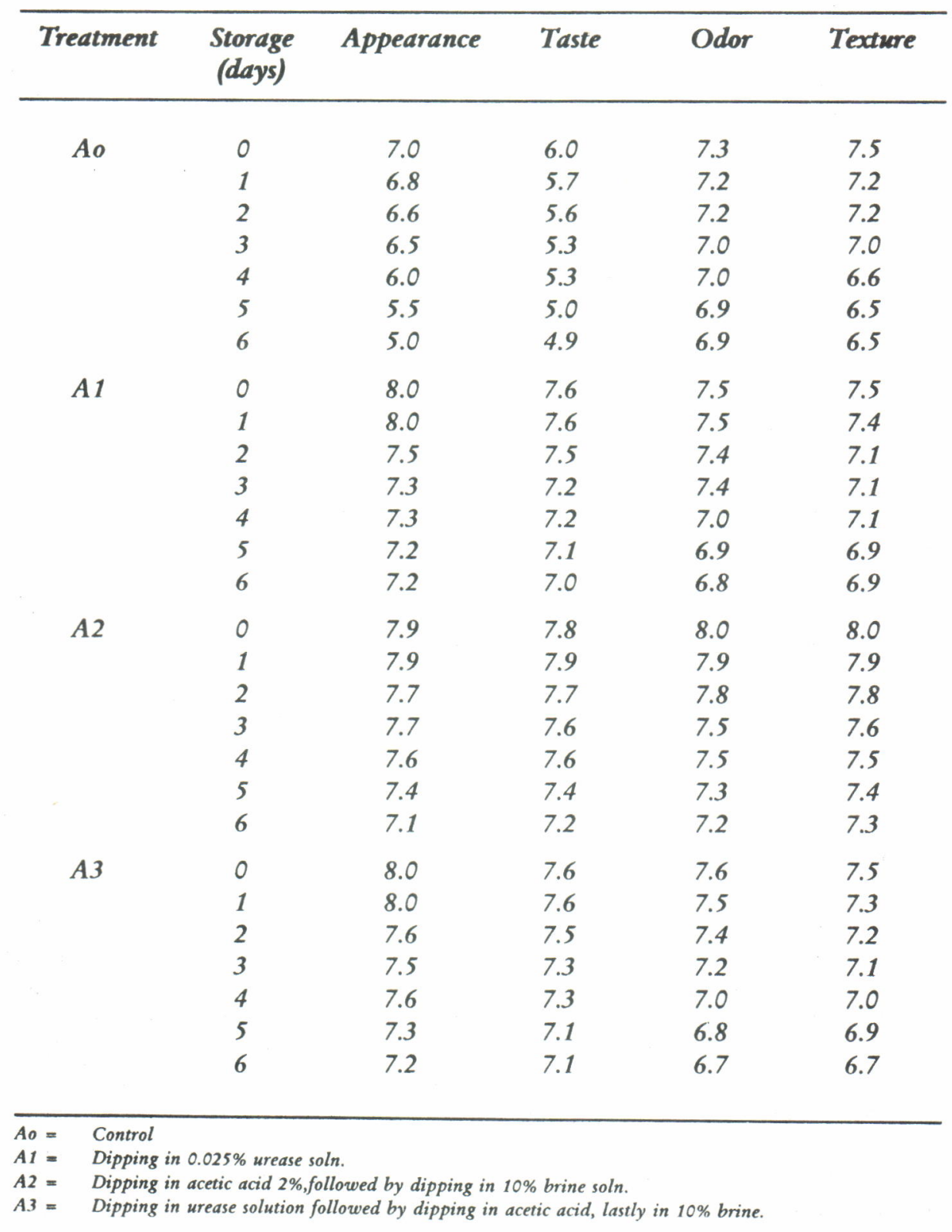


Mohammad Saleh, Irwandi, F. G. Winarno dan Y. Haryadi

Table 6. Organoleptic score of smoked shark meat during storage at low temperature

\begin{tabular}{cccccc}
\hline Treatment & $\begin{array}{c}\text { Storage } \\
\text { (days) }\end{array}$ & Appearance & Taste & Odor & Texture \\
\hline A0 & 0 & 7.0 & 6.0 & 7.3 & 7.5 \\
& 8 & 7.0 & 5.8 & 7.3 & 7.2 \\
& 16 & 6.9 & 5.5 & 7.2 & 7.0 \\
& 24 & 6.7 & 5.0 & 7.0 & 6.7 \\
A1 & 0 & 8.0 & 7.6 & 7.5 & 7.5 \\
& 8 & 8.2 & 7.5 & 7.4 & 7.3 \\
& 16 & 8.0 & 7.4 & 7.4 & 7.0 \\
& 24 & 7.8 & 7.2 & 7.0 & 6.9 \\
A2 & 0 & 7.9 & 7.8 & 8.0 & 7.5 \\
& 8 & 8.0 & 7.7 & 8.0 & 7.2 \\
& 16 & 7.9 & 7.5 & 7.8 & 7.1 \\
& 24 & 7.7 & 7.4 & 7.7 & 6.8 \\
\multirow{4}{*}{ A3 } & 0 & 8.0 & 7.6 & 7.5 & 7.5 \\
& 8 & 8.0 & 7.5 & 7.4 & 7.2 \\
& 16 & 7.9 & 7.5 & 7.3 & 7.0 \\
& 24 & 7.7 & 7.4 & 7.1 & 6.9 \\
\hline
\end{tabular}

Ao $=$ Control

$A 1=$ Dipping in $0.025 \%$ urease soln.

A2 - Dipping in actic acid 2\%,followed by dipping in $10 \%$ brine soln.

$A 3=$ Dipping in urease solurion followed by dipping in acetic acid, lastly in $10 \%$ brine.

\section{Rupa/penampakan}

Pada Table 5 dan Table 6 terlihat bahwa skor rupa contoh kontrol lebih rendah daripada contoh A1, A2 dan A3. Hal ini menunjukkan bahwa perlakuan perendaman dapat meningkatkan skor rupa produk asap. Dari analisis ragam terlihat bahwa contoh yang disimpan pada suhu kamar, jenis perlakuan perendaman berpengaruh nyata terhadap skor rupa/penampakan, tetapi tidak berpengaruh nyata terhadap contoh yang disimpan pada suhu rendah. Pada contoh yang disimpan pada suhu kamar, skor yang diberikan panelis kepada contoh kontrol jauh di bawah skor yang diberikan untuk ketiga contoh lainnya. Penampakan atau warna ikan asap terutama disebabkan oleh adanya senyawa fenol yang diserap selama proses pengasapan dan reaksi-reaksi yang ditimbulkannya (Syarief, 1976). Timbulnya perbedaan antara penampakan ikan asap tersebut kemungkinan karena jumlah fenol pada contoh kontrol lebih sedikit dibandingkan yang lain. Selama penyimpanan skor penampakan 
untuk semua contoh cenderung menurun, hal ini sejalan dengan semakin berkurangya kadar fenol. Selain itu juga aktivitas mikroorganisme juga berpengaruh terhadap penampakan produk, hal ini jelas terlihat pada contoh kontrol yang sudah ditumbuhi kapang sebelum hari terahir pengamatan.

b. Bau

Pada kedua kondisi penyimpanan ternyata analisis ragam tidak memperlihatkan adanya pengaruh nyata dari jenis perlakuan perendaman terhadap skor aroma daging cucut asap. Pada hari ke 0 skor aroma berkisar antara 7,3-8,0, dan pada hari terakhir turun menjadi sekitar 6,7-7,2 untuk contoh yang disimpan pada suhu kamar dan sekitar 7,0-7,7 untuk yang disimpan pada suhu rendah.

Selama penyimpanan skor aroma cenderung menurun, hal ini sejalan dengan meningkatnya amoniak, TVB dan TPC. Meningkatnya jumlah mikro organisma menyebabkan semakin banyaknya terbentuk senyawa yang menghasilkan bau dan rasa tidak enak (Ketaren, 1986).

\section{c. Rasa}

Hasil analisis sidik ragam menunjukkan bahwa jenis perlakuan perendaman berpengaruh sangat nyata terhadap rasa daging cucut asap, baik yang disimpan pada suhu kamar maupun pada suhu dingin. Skor untuk rasa daging cucut asap yang mengalami perlakuan perendaman sebelumnya jauh di atas contoh yang tidak mengalami perendaman (kontrol). Hal ini disebabkan karena garam dan asam asetat merupakan komponen pemberi cita rasa. Selama perendaman contoh menyerap kedua senyawa tersebut sehingga mempengaruhi rasa. Selama penyimpanan skor rasa contoh yang mengalami perlakuan perendaman berfluktuasi meskipun pada tahap akhir penyimpanan cenderung menurun. Penurunan skor rasa ini terlihat jelas pada daging cucut asap kontrol. Hal ini mungkin disebabkan oleh aktivitas mikroorganisme yang menghasilkan berbagai senyawa seperti indol, skatol, hidrogen sulfida, amoniak dan asam-asam organik yang menimbulkan rasa yang tidak enak (Ketaren, 1986).

\section{d. Tekstur}

Analisis sidik ragam menunjukkan bahwa jenis perlakuan perendaman tidak berpengaruh nyata terhadap skor tekstur daging cucut asap pada kedua kondisi penyimpanan. Pada hari ke 0 , skor tekstur untuk semua contoh sama yaitu 7,5. Tidak berpengaruhnya perlakuan perendaman dalam larutan garam dan larutan asam terhadap skor tekstur produk kemungkinan karena waktu perendaman yang relatif singkat sehingga efeknya terhadap tekstur tidak dapat dideteksi oleh panelis. Selama penyimpanan skor tekstur menurun hingga 
mencapai 6,5-6,7 untuk contoh yang disimpan pada suhu kamar dan 6,7-6,9 untuk contoh yang disimpan pada suhu rendah. Penurunan skor tekstur ini kemungkinan karena terjadinya penguraian struktur protein akibat aktivitas mikroorganisme yang menyebabkan terbebasnya air terikat sehingga kadar air bebas meningkat yang selanjutnya mempengaruhi tekstur produk (Winarno et al., 1980).

\section{KESIMPULAN}

1. Perlakuan perendaman dalam larutan urease sangat efektif untuk mengurangi kadar urea yang ada dalam daging ikan cucut segar. Walaupun kombinasi perendaman dalam larutan urease dan larutan garam serta asetat dapat meningkatkan efektifitas larutan urease namun tidak ekonomis.

2. Daya awet daging cucut asap pada suhu kamar hanya $\mathbf{4}$ hari dan pada suhu rendah lebih dari 24 hari. Ketiga perlakuan perendaman dapat memperpanjang daya awet cucut asap pada suhu kamar dari 4 hari menjadi lebih dari 6 hari.

3. Selama penyimpanan daging cucut asap baik pada suhu kamar maupun suhu rendah terjadi penurunan kadar air, urea, dan fenol sedangkan TVB, amoniak dan TPC mengalami peningkatan.

4. Kapang yang tumbuh pada daging cucut asap yang disimpan pada suhu kamar adalah Aspergillus sp., A.niger, Penicillium sp. dan Alternaria sp., sedangkan pada suhu rendah Aspergillus sp. dan A.niger.

\section{DAFTAR PUSTAKA}

Anonimous. 1974. Metode dan prosedur analisis kimia hasil perikanan. Lembaga Teknologi Perikanan, Jakarta.

A.O.A.C. 1970. Association of Official Analytical Chemist. Washington DC.

A.O.A.C. 1980. Association of Official Analytical Chemist. Washington DC.

Berhimpon, S. 1982. Pengaruh perendaman filet (fillet) di dalam larutan asam asetat terhadap kandungan urea dan mutu daging ikan hiu (Carcbarbinus limbatus) selama penyimpnan. Program Pascasarjana IPB Bogor.

Cutting, C.L. 1965. Smoking. Di dalam Fish as Food. Edited by G. Borgstorm, Vol.III. Academic Press, New York.

Ketaren, S. 1986. Pengantar teknologi minyak dan lemak pangan. U.I. Press, Jakarta. 
Motohiro, T. 1988. Effects of smoking and drying on the nutritive value of fish. A review of Japanese Studies dalam Fish smoking and drying, edited by J.R. Burt. Elsevier Applied Science. London and New York.

Pitt, J.I. dan A.D.Hocking. 1985. Food science and technology. A series of Monographs Fungi and Food Spoilage. The Academic Press, Australia.

Priono, B., Suparno, Y. Sudrajat dan N. Haq. 1984. Perlakuan phisis dan khemis untuk mengurangi kandungan urea dalam daging cucut. Laporan Penelitian Teknologi Perikanan,No.38.

Sabaruddin, Tazwir dan Sastrawijaya. 1987. Uji coba pemanfaatan cucut (Carcharbinus sp.) di Pelabuhan Ratu Jawa Barat: daging cucut untuk abon. Jurnal Penelitian Pasca Panen Perikanan, No.59. Jakarta.

Saleh, M., W. Juwono, S.T. Sukarto dan Subarna. 1990. Pengolahan tepung ikan untuk pangan dari daging cucut (Carcharbinus sp.). Jurnal Penelitian Pasca Panen Perikanan, No. 66.

Simidu, W. 1961. Non protein nitrogenous compound. Di dalam Fish as food, Vol. I (G. Borgstorm, Edt.) Academic Press New York.

Soedijono, N.H., L. Hutuely, N.H. Haerudin dan T.A.R. Hanafiah. 1984. Pengaruh penambahan potasium sorbat pada pengolahan cakalang asap terhadap daya awetnya. Laporan Penelitian Teknologi Perikanan Laut. No.33, B.P.P.L. Jakarta.

Syarief, M. 1976. Pembuatan ikan kayu di Aertembaga Sulawesi Utara. Universitas Brawijaya Afiliasi Fak. Perikanan IPB Bogor.

Weast, R.C. 1976. Handbook of chemistry and physics. CRC Press, Ohio.

Winarno, F.G., S. Fardiaz dan D. Fardiaz. 1980. Pengantar Teknologi Pangan. P.T. Gramedia, Jakarta. 